\title{
Vertical distribution of zooplankton in the water column of Lago Amapá, Rio Branco, Acre, Brazil
}

\author{
Erlei Cassiano Keppeler ${ }^{1} \&$ Elsa Rodrigues Hardy ${ }^{2}$ \\ 1 Programa de Pós-Graduação em Aqüicultura, Centro de Aqüicultura, Universidade Estadual Paulista. Rodovia Carlos \\ Tonanni, 14870-000 Jaboticabal, São Paulo. E-mail: erlei@caunesp.unesp.br \\ ${ }^{2}$ Laboratório de Zooplancton, Instituto Nacional de Pesquisas da Amazônia. Avenida André Araújo, 69060-001 Manaus, \\ Amazonas, Brasil.
}

\begin{abstract}
The aim of investigation was to study the model of vertical distribution in Lago Amapá, taking into consideration the seasonality of its zooplanktonic composition. Lago Amapá $\left(10^{\circ} 2^{\prime} 36^{\prime \prime} \mathrm{S}\right.$ and $\left.67^{\circ} 50^{\prime 2} 24^{\prime \prime} \mathrm{W}\right)$ is located in the floodplain of the Rio Acre. Samplings were conducted at three different depths of the water column, to study the vertical distribution of zooplankton populations and determine some physico-chemical and biological parameters of Lago Amapá. Weekly samples were taken with a Van Dorn sampler. The species showed greater concentrations at the by means of water column. Thirty-eight zooplankton species were found in the samples represented by Rotifera (30), Cladocera (5) and Cyclopoida (3). The temperature of the water column showed a tendency toward relatively high values (about $30^{\circ} \mathrm{C}$ ) with little variation, consequently resulting in low viscosity. Based of Jaccard's index, it was seen that during the low-water phase, $\mathrm{S} 1$ and $\mathrm{S} 3$ of the three sampling stations studied, had greater similarity $\left(C_{i}=0.7058\right)$ in the middle of the water column. Lago Amapá showed characteristics in line with the intermediate disturbance hypothesis model, favoring colonization by opportunistic species such as rotifers.

KEY WORDS. Floodplain, intermediate disturbance hypothesis, zooplankton species.
\end{abstract}

RESUMO. O objetivo desta investigação foi observar a distribuição vertical da comunidade do zooplâncton no Lago Amapá (10²'36"S e 6750'24"W), localizado na planície de inundação do Rio Acre. Amostragens foram conduzidas em três diferentes profundidades da coluna da água, considerando aspectos sazonais do zooplâncton, parâmetros físicos, químicos e biológicos. Coletas foram realizadas semanalmente com Garrafa de Van Dorn. As espécies apresentaram maiores concentrações no meio da coluna da água. Foram encontradas 38 espécies, assim distribuídas: Rotifera (30), Cladocera (5) e Cyclopoida (3). A temperatura da coluna da água em geral apresentouse alta, em torno de $30^{\circ} \mathrm{C}$, com pequena variação, resultando em baixa viscosidade. $O$ índice de Jaccard, comparando-se as três estações de coletas, demonstrou que durante a fase de águas baixas, as estações 1 e 3 foram as mais similares $\left(C_{i}=0.7058\right)$, especialmente no meio da coluna da água. Lago Amapá apresentou características em conformidade com o Modelo do Distúrbio Intermediário, favorecendo a colonização de grupos oportunistas, tais como rotiferos.

PALAVRAS CHAVE. Espécies zooplanctônicas, planície de inundação, hipótese do distúrbio intermediário.

All the biocenose possesses a particular structure that corresponds to the disposition of the individuals of the various species in relation to each other, in both the vertical and horizontal plane. According to WiLliamson et al. (1996), many planktonic organisms exhibit daily vertical migrations in response to the daily oscillations of several environmental variables. The distribution of planktonic communities is influenced by the intermediate disturbance hypothesis proposed by ConNell (1978), that is, high diversity is at intermediate levels of disturbance.
The intermediate disturbance hypothesis furnishes an explanation for the fact that the majority of ecosystems are far from being at climax or dynamic equilibrium or in a stable state, in accordance with the theory of ecological succession. This holds true as long as for the majority, a period of time has elapsed sufficient for this to be attained. The structure of communities that undergo intermediate perturbations, have their development, or autogenic succession, delayed, interrupted or destroyed. This allows the term "intermediate" to be applied 
with respect to two meanings, that is, referring to medium intensity or to a disturbance that occurs with an intermediate succesive step. Disturbance is the main determinant of community structure, with the important element of time influencing the level of diversity that is established after the event. When it is frequent, it can become a requirement of the community it creates. It is this consistency of disturbance that is at the core of the intermediate disturbance hypothesis (ConNelL 1978, Reynolds et al. 1993, Harper 1978). Periodic flooding of abandoned meander lakes, common in aquatic ecosystems in Amazonia, are events that exemplify these perturbations that influence the zooplanktonic communities present.

Limnologic studies, including those on vertical distribution, are still scarce. Some existing interrelations between organisms and physico-chemical parameters, considering vertical distribution, have been studied by LeWIS \& WeIBEZAHN (1976), INFANTE (1980), and BINI et al. (2001). The existing differences in the vertical distribution of zooplankton species are probably determined by an interaction among physical, chemical and biological factors, such as predation and competition.

Such studies conducted in Brazil have examined mainly the daily variation of the floodplain of the Rio Paraná (PAES DA Silva \& Thomaz 1997). Fisher et al. (1983), in studies of Lago Calado in Central Amazônia found microcrustaceans in the oxygenated layer, with no evident vertical migration.

The aim of this study was to determine the patterns of vertical distribution, taking into consideration the seasonality of the composition of the zooplankton community, and some abiotic variables of Lago Amapá and of the floodplain of Rio Acre in the morning, during the main phases of the hydrologic cycle.

\section{MATERIAL AND METHODS}

In the areas of the Amazonia lowlands, the character of the Andean rivers develop strong lateral incisions instead of showing depth erosion, resulting in meandering. After passing their cones of coarse rubble, deposited when leaving the mountainous section of their courses, the rivers carry a bottom-load of sand which forms sandbanks, and their waters become turbid, because of their load of fine suspended particles. The meanders migrate down the rivers, old ones are cut off and transformed into oxbow lakes, and new ones are formed. The whole land adjacent to the rivers is in a constant and rapid process of dismantling and rebuilding, a process which can be observed on a time scale of a few decades (Sioli 1984).

The lake studied is environment situated in the Amazon Basin. Lago Amapá is situated in the municipality of Rio Branco with the geographic coordinates $10^{\circ} 02^{\prime} 36^{\prime \prime} \mathrm{S}$ and $67^{\circ} 50^{\prime} 24^{\prime \prime} \mathrm{W}$ (Fig. 1). It is an affluent of the Rio Acre, characterized according to SIOLI (1984) as a whitewater river with turbid water, more or less ochre-colored water; this type of river is well regarded in the pre-Andean zone as southwestern. One of the main char-
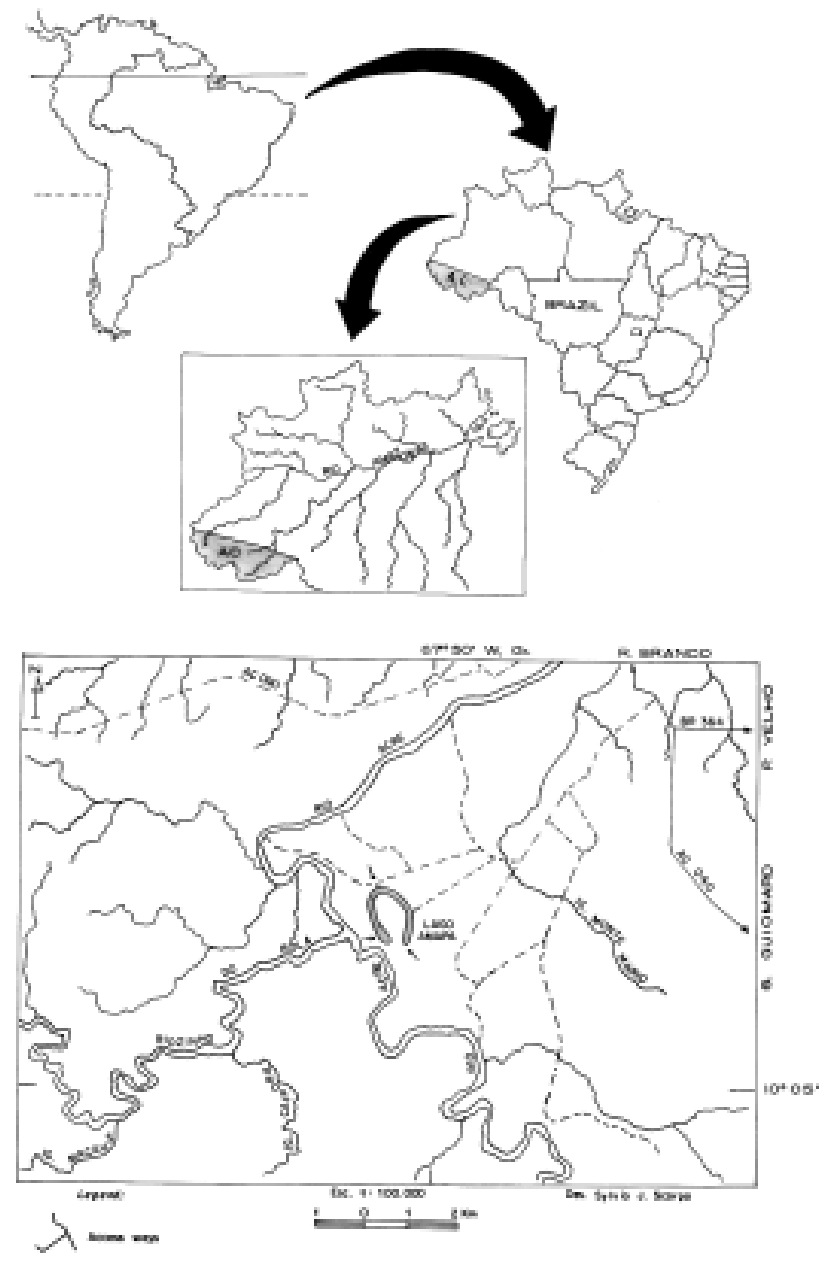

Figure 1. Studied Area.

acteristics of the lakes studied is the fluctuation of the water level, which is distinguished by two phases: high water and low water. They are directly influenced by the hydrologic regime of the Rio Acre, especially during high water periods. These lakes are abandoned meanders. The minimum and maximum depths for Lago Amapá are respectively 2.7 and $4.5 \mathrm{~m}$.

According to SALATI et al. (1978), the hydrologic complex, which is the Amazon basin, is formed by thousands of small rivers and has probably been in dynamic equilibrium, together with the exuberant forest, for millennia. The lakes studied are situated south of the equator, beyond parallel $65^{\circ} \mathrm{W}$, and receive a minimum amount of precipitation in June/July (SIOLI 1984). Lago Amapá is a lake belonging to the hydrographic basin of the Rio Acre, to which it is permanently linked, and thus considered a whitewater lake, according to Sioli (1968). The lakes are surrounded by forest, which is inundated during high water, and as a consequence, there is a great input of organic matter from the forest into the lake.

Revista Brasileira de Zoologia 21 (2): 169-177, junho 2004 
The data on the biotic and abiotic parameters were collected at the lake generally at weekly intervals (except in October), during two periods comprising the the low-water phase (dry season) between May 8, 1997 and October 30, 1997 and the high-water phase (rainy season) between January 2, 1998 and February 24, 1998. Three stations were selected: station Ia region located close to a canal that connects Lago Amapá with Rio Acre; station II - an approximately central region of the lake; station III; the terminal region of the lake.

To carry out a qualitative and quantitative analysis of the zooplankton, 5-L aliquots were collected from each layer (top, middle and bottom) of the water column. The zooplankton organisms were collected with a Van Dorn sampling bottle, using a conical net (55- $\mu \mathrm{m}$ mesh) to filter 15 liters of water at the different dephts.

The samples were preserved in a solution of $4 \%$ formaldehyde. The determination of the physical, chemical and biological parameters, that is, water temperature $\left({ }^{\circ} \mathrm{C}\right)$, transparency and depth of the water column (m), electrical conductivity $\left(\mu \mathrm{S} . \mathrm{cm}^{-1}\right)$, dissolved oxygen $\left(\mathrm{mg} . \mathrm{L}^{-1}\right)$ and chlorophyll- $a$ ( $\left.\mu \mathrm{g} . \mathrm{L}^{-1}\right)$, was according to Golterman et al. (1978), and included a modification of the assay for dissolved oxygen using sodium azide (Golterman et al. 1969). Alkalinity was determined by a titrometric method according to MACKERETH et al. (1978).

The qualitative similarity between the populations of the different collection locations was calculated using Jaccard's Index (Krebs 1989) as follows: $\mathrm{C}_{\mathrm{j}}=\mathrm{a} / \mathrm{a}+\mathrm{b}+\mathrm{c}$, where $\mathrm{C}$ is the index, $a$ is the number of species present in both locations, $b$ is the number of species present only in location $\mathrm{A}$, and $\mathrm{c}$ is the number of species present only in location $\mathrm{B}$. The presence of a species in at a collection location was scored as 1 , and its absence was scored as 0 .

\section{RESULTS AND DISCUSSION}

\section{Physical and chemical parameters and their influence on the presence of zooplankton}

The hydrometric levels obtained for the Rio Acre, in accordance with the data furnished by the Civil Defense of the Rio Branco Corp of Firemen for the period studied (low-water phase/1997 and high-water phase/1998), remained practically constant up to almost the end of the low-water phase. However, from October, it increased considerably up to the second half of February in the high-water phase.

As a result of the qualitative analysis of the zooplankton, 30 taxa de rotifers, five taxa of cladocers and four taxa of copepods were found. The species of Rotifera found were: Asplanchna brightwelli Gosse 1850; Asplanchna sieboldi (Leydig, 1850); Brachionus calicyflorus Pallas, 1766; Brachionus calicyflorus anuraeformis (Brehm, 1903); Brachionus caudatus (Barrois \& Daday, 1884), Brachionus dolabratus Harring, 1915; Brachionus falcatus (Zacharias, 1898); Brachionus havanaensis Rousselet, 1911; Brachionus plicatilis (O.F. Müller, 1786), Keratella americana
(Carlin, 1943); Keratella cochlearis Gosse, 1851; Keratella cochlearis hispida Lauterborn, 1900; Platyias quadricornis (Ehrenberg, 1834); Epiphanes macrourus (Barrois \& Daday, 1894); Filinia longiseta (Ehrenberg) 1834; Filinia opoliensis (Zacharias, 1898); Filinia pjeleri (Hutchinson, 1964), Filinia terminalis Plate 1886; Hexarthra intermedia brasiliensis (Hawer, 1953); Lepadella ovalis (O.F. Müller, 1786); Polyarthra vulgaris Carlin, 1943; Testudinella patina (Hermann, 1783); Trichocerca similis (Wierzejski, 1893); Trochosphaera aequatorialis Semper, 1872. The cladocers were: Bosminopsis deitersi (Richard, 1895); Ceriodaphnia cornuta SARS, 1886; Diaphanosoma spinulosum Herbst, 1975; Moina minuta Hansen, 1899; Moina reticulata (Daday, 1905); and copepod Neutrocyclops brevifurca (Lowdes, 1934). Moreover, were determined genera of species without identification: Rotifera (6) and Copepoda (1). Also found were juvenile forms such as nauplii, copepodites of Cyclopoida and Calanoida, and other invertebrates such as Chaoboridae.

Among the collection stations, the most similarities, based on zooplankton composition, were found for stations S1 and S3 during the low-water phase (Tab. I).

Table I. Comparison of the different collection stations (S1, S2 and S3) at Lago Amapa, taking into consideration the diverse compartments of the water column according to Jaccard's index, at low and high water.

\begin{tabular}{llll}
\hline & S1xS2 & S1xS3 & S2xS3 \\
\hline Low-water phase & & & \\
Surface & 0.6956 & 0.6956 & 0.6521 \\
Middle & 0.6666 & 0.7058 & 0.5789 \\
Bottom & 0.4705 & 0.2666 & 0.6923 \\
High-water phase & & & \\
Surface & 0.4000 & 0.4615 & 0.6086 \\
Middle & 0.5833 & 0.3000 & 0.2857 \\
Bottom & 0.4500 & 0.5500 & 0.3000 \\
\hline
\end{tabular}

Greater similarities occurred during the low-water phase, by virtue of the separation of waters from Lago Amapá and the Rio Acre. The zooplankton was found to be distributed throughout the water column, showing a greater abundance of rotifers during both periods, which were concentrated in the middle and the top of the water column in the dry season, and preferentially in the top layer in the rainy season (Fig. 2).

In the dry season, the zooplankton had a defined pattern of distribution, clearly with a greater density in the middle and the top of the water column, since the bottom regions of stations 3 and 1 formed separate groups. Station 2 is calmer than station 3 and deeper than station 1. (Fig. 2). On the other hand, at high water, a greater distribution of organisms is seen throughout the water column, with the exception of station 


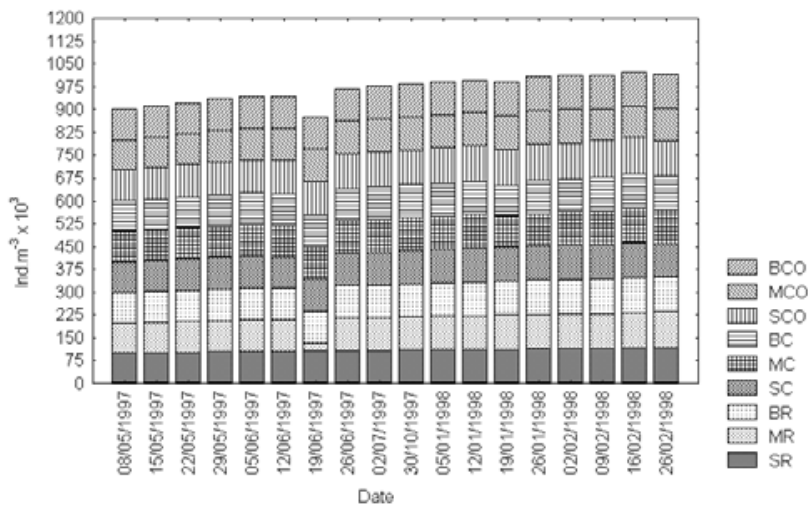

Figure 2. Distribution of zooplankton in different layers of the water column. Legends: Rotifera in - (SR) surface, (MR) middle, (BR) bottom; Cladocera in - (SC) surface, (MC) middle, (BC) bottom; Copepoda in -(SCO) surface, (MCO) middle, (BCO) bottom.

3 , which is a deeper station. This distribution can be explained by the more elevated levels of chlorophyll- $a\left(145 \mu \mathrm{g} .1^{-1}\right)$ in the middle of the water column recorded during the low-water phase, with the inverse occurring in the rainy season. The water column was shown to be generally oxygenated, with lower values at the end of the low-water phase (Tabs II and III).

The values for dissolved oxygen accompanied the temperature. They were also generally high in the top layer, and at times high values were also seen in the bottom layer, contrary to studies conducted by PaEs Da SiLva \& Thomaz (1997), who found values close to zero in the bottom layer. Oxygenation was much greater in the upper layers, permitting a propitious habitat, as was the survival of the zooplankton populations.

The more elevated concentrations of chlorophyll- $a$ occurred in the low-water period, primarily at the end, during which there was also an abundance of particular zooplankton groups because of the abundance of food.

Temperature did not appear to be the cause of this distribution, since it showed small variations of only $1^{\circ}$ to $3^{\circ} \mathrm{C}$ during low water, and of $0^{\circ}$ to $1^{\circ} \mathrm{C}$ during high water. Similarly, $\mathrm{pH}$ did not vary substantially, showing values generally in the acid range. With regard to vertical distribution, the middle and bottom of the water column did not show any stratification during the course of the study.

Lago Amapá showed seasonal patterns influenced by the elevation of the water level of the Rio Acre during the highwater period. During this phase, there was greater transparency, concomitant with the fall in chlorophyll- $a$ values. However, transparency accompanied proportionally the concentration of dissolved oxygen. Esteves et al. (1994) explained that the penetration of light to the bottom favors a high photosynthetic activity throughout the water column. Temperature remained nearly constant the entire period, and among the dif- ferent water layers as well, sometimes by the fact that the lake was calm, showing thus the absence of stratification. There was thereby a tendency for organisms to be distributed throughout the water column, not determining defined niches.

The $\mathrm{pH}$ appeared to be generally homogeneous in the water column, while electrical conductivity was greater at the bottom. Esteves et al. (1994) also observed in Lago Batata a homogeneous $\mathrm{pH}$ and high values of electrical conductivity, mainly at the bottom, due to the accumulation of ions resulting from the decomposition of organic material and from the contact of the water with the sediment.

The number of zooplanktonic organisms was reduced, at the end of the low-water phase as well as at the end of the high-water phase, possibly due to the fluctuations in the water level, which causes stress to the organisms.

Two species of the genus Keratella were examined in this study. The species $K$. cochlearis was more abundant, and occurred in the intermediate layer of the water column, which also showed low $\mathrm{pH}$ values and high levels of chlorophyll- $a$. A peak was shown on June 5 (during the dry season) in all three layers of the water column. In the rainy season, the density diminished drastically, and this species was replaced by $K$. cochlearis hispida, with density peaks in the top layer (Fig. 3), which appeared to adapt better to the changes in $\mathrm{pH}$ from neutral to slightly basic during the dry season to acidic during the rainy season, along with a reduction in chorophyll-a.

Three species of the genus Filinia were identified. F. opoliensis and $F$. longiseta had two similar density peaks and were present during all the study period, in contrast to $F$. terminalis, which showed lower densities, mainly at low water. Only one density peak was evident at high water, as of January 19 , in the top and middle layers of the water column. Brachionus falcatus, abundant in the low-water phase, was succeeded in the high-water phase by Brachionus calicyflorus and B. calicyflorus anuraeformis, present in all three layers, although the greater density being seen preferentially in the top layer (Fig. 3). When this occurred, there was also a greater electrical conductivity during this phase.

Greater peaks for Filinia terminalis, Brachionus calicyflorus, Brachionus calicyflorus anuraeformis and Keratella cochlearis hispida occurred when there was greater electrical conductivity during the high-water phase, especially on January 19, 1998.

Alkalinity, $\mathrm{pH}$ and electrical conductivity had higher values in the low-water than in the high-water period, which possibly favored the presence during low water of Brachionus falcatus, Filinia opoliensis, Filinia longiseta, Keratella cochlearis and Moina minuta.

The density levels obtained for microcrustaceans (Cladocera) are shown in figure 3. Moina minuta was predominant in the middle of the water column, mainly during the dry season, while Diaphanosoma spinulosum showed a peak in the top layer during this phase, but was distributed among all three layers in the rainy season. 

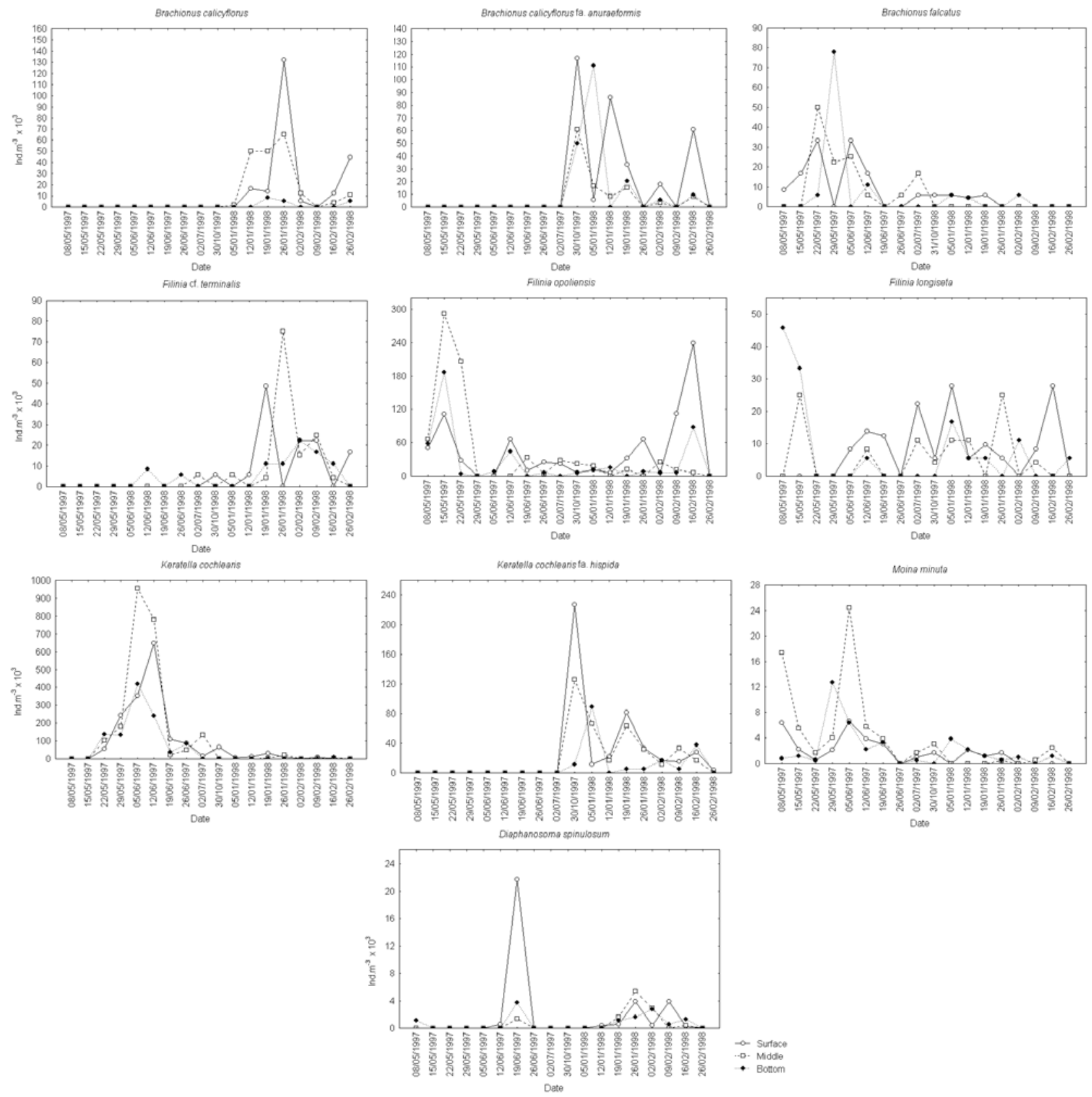

Figure 3. Vertical distribution of zooplankton species in the surface, middle and bottom layers of the water column of Lago Amapá.

Figure 4 describes the variation in population density for Chaoboridae during the two main phases of the hydrologic cycle, where it is seen that this species occupied preferentially the middle layer mainly during the dry season. The number of Chaoboridae was much greater during the low-water phase.

\section{Seasonal succession of zooplankton and spatial distribution of the taxa}

The results obtained in this study show that zooplankton species are distributed throughout the water column, principally during the high-water phase, with the entrance of water from the river beginning January 19, 1998, making new

Revista Brasileira de Zoologia 21 (2): 169-177, junho 2004 
Table II. Physico-chemical and biological parameters measured at Lago Amapá during the low water phase of the hydrologic cycle in 1997.

\begin{tabular}{|c|c|c|c|c|c|c|c|c|c|c|}
\hline \multirow{2}{*}{ Var } & & \multirow{2}{*}{$\frac{\text { Depth (m) }}{M \pm S D}$} & \multirow{2}{*}{$\frac{\text { Trans (m) }}{M \pm S D}$} & \multirow{2}{*}{$\frac{\mathrm{T}\left({ }^{\circ} \mathrm{C}\right)}{\mathrm{M} \pm \mathrm{SD}}$} & \multirow{2}{*}{$\frac{\text { Alk (Meq.L-1) }}{M \pm S D}$} & \multirow{2}{*}{$\frac{\mathrm{pH}}{\mathrm{M} \pm \mathrm{SD}}$} & \multicolumn{2}{|c|}{ Cond ( $\mu$ S.cm-1) OD (mg.L-1) } & Chlor ( $\mu$ g.L-1) & \multirow{2}{*}{$\frac{\mathrm{L}(\mathrm{m})}{\mathrm{M} \pm \mathrm{SD}}$} \\
\hline & & & & & & & $M \pm S D$ & $M \pm S D$ & $M \pm S D$ & \\
\hline \multirow[t]{3}{*}{$08 / 05$} & $S$ & $2.50 \pm 1.24$ & $0.26 \pm 0.28$ & $27.83 \pm 0.76$ & $7.50 \pm 4.27$ & $6.83 \pm 0.20$ & $59.61 \pm 2.08$ & $5.23 \pm 2.45$ & $9.98 \pm$ & - \\
\hline & M & & & $27.00 \pm 1.00$ & $21.00 \pm 12.75$ & $6.70 \pm 0.30$ & $59.30 \pm 1.15$ & $1.90 \pm 0.40$ & $6.86 \pm$ & \\
\hline & B & & & $26.16 \pm 1.04$ & $21.30 \pm 17.60$ & $6.56 \pm 0.15$ & $52.00 \pm 25.05$ & $1.10 \pm 0.75$ & $7.74 \pm$ & \\
\hline \multirow[t]{3}{*}{$15 / 05$} & S & $2.66 \pm 1.05$ & $0.15 \pm 0$ & $27.83 \pm 1.15$ & $5.50 \pm 4.76$ & $7.13 \pm 0.05$ & $31.91 \pm 20.11$ & $6.26 \pm 1.09$ & $32.20 \pm 28.25$ & $0.15 \pm 0$ \\
\hline & M & & & $27.66 \pm 1.15$ & $7.30 \pm 3.21$ & $6.93 \pm 0.05$ & $31.60 \pm 15.83$ & $3.46 \pm 1.16$ & $32.83 \pm 39.13$ & \\
\hline & B & & & $27.50 \pm 0.50$ & $5.83 \pm 5.00$ & $6.76 \pm 0.05$ & $44.10 \pm 9.35$ & $0.60 \pm 0.79$ & $14.48 \pm 11.11$ & \\
\hline \multirow[t]{3}{*}{$21 / 05$} & $S$ & $2.50 \pm 1.15$ & $0.25 \pm 0$ & $31.00 \pm 2.00$ & $31.60 \pm 2.51$ & $7.06 \pm 0.87$ & $37.20 \pm 3.26$ & $6.48 \pm 3.07$ & $32.08 \pm 22.10$ & $0.20 \pm 0$ \\
\hline & M & & & $29.66 \pm 1.52$ & $30.50 \pm 1.32$ & $7.06 \pm 0.11$ & $48.30 \pm 12.85$ & $4.56 \pm 3.19$ & $52.30 \pm 18.20$ & \\
\hline & B & & & $28.83 \pm 1.04$ & $34.83 \pm 8.83$ & $6.76 \pm 0.15$ & $57.10 \pm 13.50$ & $2.76 \pm 3.27$ & $29.58 \pm 18.30$ & \\
\hline \multirow[t]{3}{*}{$29 / 05$} & $S$ & $3.06 \pm 1.27$ & $0.28 \pm 0.28$ & - & $38.16 \pm 1.60$ & $7.40 \pm 0.17$ & $54.03 \pm 14.95$ & $8.76 \pm 1.66$ & $18.47 \pm$ & $0.40 \pm 0$ \\
\hline & M & & & - & $36.80 \pm 2.36$ & $6.83 \pm 0.15$ & $67.50 \pm 2.06$ & $6.43 \pm 0.70$ & $16.72 \pm$ & \\
\hline & B & & & - & $35.83 \pm 2.75$ & $6.80 \pm 0.43$ & $42.20 \pm 13.71$ & $1.93 \pm 3.00$ & $19.35 \pm$ & \\
\hline \multirow[t]{3}{*}{$05 / 06$} & S & $2.76 \pm 1.16$ & $0.38 \pm 0.76$ & $31.83 \pm 0.28$ & $30.83 \pm 3.81$ & $7.40 \pm 0.52$ & $65.50 \pm 6.80$ & $7.23 \pm 1.06$ & $41.32 \pm 14.60$ & $0.40 \pm 0$ \\
\hline & M & & & $30.66 \pm 1.52$ & $33.30 \pm 3.61$ & $7.16 \pm 0.32$ & $69.00 \pm 0.15$ & $5.80 \pm 1.99$ & $34.20 \pm$ & \\
\hline & B & & & $30.50 \pm 1.32$ & $33.66 \pm 1.60$ & $7.10 \pm 0.10$ & $74.00 \pm 6.46$ & $5.40 \pm 1.85$ & $43.32 \pm 11.50$ & \\
\hline \multirow[t]{3}{*}{$12 / 06$} & $S$ & $3.10 \pm 1.70$ & $0.25 \pm 0$ & $25.83 \pm 0.76$ & $31.33 \pm 7.65$ & $7.56 \pm 0.05$ & $28.90 \pm 26.12$ & $5.53 \pm 1.85$ & $57.92 \pm 36.70$ & $0.40 \pm 0$ \\
\hline & $M$ & & & $26.00 \pm 0.00$ & $35.50 \pm 1.50$ & $7.46 \pm 0.05$ & $40.10 \pm 25.77$ & $4.20 \pm 0.60$ & $28.71 \pm 17.47$ & \\
\hline & B & & & $25.00 \pm 2.00$ & $33.33 \pm 6.50$ & $7.43 \pm 0.11$ & $47.10 \pm 20.86$ & $2.10 \pm 1.49$ & $24.34 \pm$ & \\
\hline \multirow[t]{3}{*}{$19 / 06$} & $S$ & $2.30 \pm 1.15$ & $0.33 \pm 0.11$ & $28.00 \pm 1.00$ & $34.00 \pm 2.59$ & $8.70 \pm 0.96$ & $65.90 \pm 2.33$ & $4.56 \pm 1.74$ & $38.70 \pm 13.44$ & $0.50 \pm 0$ \\
\hline & M & & & $27.50 \pm 0.50$ & $34.16 \pm 3.05$ & $8.70 \pm 1.05$ & $64.00 \pm 2.90$ & $2.86 \pm 1.10$ & $44.94 \pm 33.29$ & \\
\hline & B & & & $26.16 \pm 2.75$ & $35.83 \pm 3.01$ & $8.33 \pm 2.28$ & $68.00 \pm 3.78$ & $1.53 \pm 0.20$ & $33.08 \pm 27.68$ & \\
\hline \multirow[t]{3}{*}{$26 / 06$} & $S$ & $2.60 \pm 1.17$ & $0.45 \pm 0.05$ & $28.33 \pm 0.57$ & $39.33 \pm 6.37$ & $7.80 \pm 0.88$ & $62.60 \pm 7.87$ & $4.20 \pm 2.47$ & $51.56 \pm 17.36$ & $1.00 \pm 0$ \\
\hline & M & & & $29.50 \pm 1.73$ & $32.16 \pm 4.31$ & $8.26 \pm 0.50$ & $53.30 \pm 23.81$ & $3.38 \pm 2.50$ & $56.67 \pm$ & \\
\hline & B & & & $28.66 \pm 0.57$ & $34.00 \pm 5.63$ & $8.53 \pm 0.15$ & $58.80 \pm 14.45$ & $2.13 \pm 2.07$ & $57.05 \pm$ & \\
\hline \multirow[t]{3}{*}{$02 / 07$} & $S$ & $2.30 \pm 1.05$ & $0.28 \pm 0.28$ & $26.00 \pm 1.00$ & $38.33 \pm 1.44$ & $7.50 \pm 0.20$ & $77.10 \pm 5.40$ & $2.06 \pm 0.76$ & $45.45 \pm$ & $0.90 \pm 0$ \\
\hline & M & & & $25.66 \pm 0.57$ & $34.33 \pm 1.15$ & $7.46 \pm 0.25$ & $76.20 \pm$ & $2.43 \pm 0.51$ & $45.84 \pm 17.43$ & \\
\hline & B & & & $25.33 \pm 0.57$ & $40.00 \pm 4.33$ & $7.53 \pm 0.05$ & $70.90 \pm$ & $2.36 \pm 1.15$ & $55.55 \pm$ & \\
\hline \multirow[t]{3}{*}{$30 / 10$} & $S$ & $2.40 \pm 1.00$ & $0.35 \pm 0.05$ & $32.66 \pm 1.52$ & $37.66 \pm 2.02$ & $8.36 \pm 1.72$ & $64.80 \pm 1.00$ & $6.60 \pm 3.17$ & $89.76 \pm 40.25$ & $0.80 \pm 0$ \\
\hline & M & & & $31.50 \pm 1.00$ & $36.00 \pm 1.32$ & $8.13 \pm 0.51$ & $65.80 \pm$ & $5.23 \pm 1.10$ & $202.99 \pm 128.28$ & \\
\hline & B & & & $30.83 \pm 1.04$ & $36.50 \pm 3.60$ & $7.26 \pm 0.66$ & $67.20 \pm$ & $2.40 \pm 0.98$ & $43.94 \pm 14.68$ & \\
\hline
\end{tabular}

(X) Mean, (SD) standard deviation, (trans) transparency, (T) temperature, (Alk) alkalinity, (Cond) electrical conductivity, (DO) dissolved oxygen, (Chlor) chlorophyll-a, (L) water level, (-) loss of samples, (S) surface, (M) middle, (B) bottom.

habitats, especially for some species of the more abundant rotifers such as Filinia longiseta, Filinia terminalis, Keratella cochlearis hispida, Brachionus calicyflorus and Brachionus calicyflorus anuraeformis. In addition, in the low-water phase, some associations are established among the taxa Brachionus falcatus, Filinia opoliensis, Filinia longiseta and Keratella cochlearis.
Rotifers occurred in greater abundance in the top layer, and less in the middle and bottom of the water column. In general, they do not appear to be associated with the predation of Chaoboridae, since the number of Chaoboridae in this layer was low in both phases of the hydrologic cycle. This study demonstrated that predation does not play a principal role in

Revista Brasileira de Zoologia 21 (2): 169-177, junho 2004 
Table III. Physico-chemical and biological parameters measured at Lago Amapá during the high phase in 1998.

\begin{tabular}{|c|c|c|c|c|c|c|c|c|c|c|}
\hline \multirow{2}{*}{ Var } & & Depth (m) & Trans (m) & $\mathrm{T}\left({ }^{\circ} \mathrm{C}\right)$ & Alk (Meq.L-1) & $\mathrm{pH}$ & Cond $(\mu S . c m-1)$ & OD (mg.L-1) & Chlor $(\mu \mathrm{g} . \mathrm{L}-1)$ & $\mathrm{L}(\mathrm{m})$ \\
\hline & & $M \pm S D$ & $M \pm S D$ & $M \pm S D$ & $M \pm S D$ & $M \pm S D$ & $M \pm S D$ & $M \pm S D$ & $M \pm S D$ & $M \pm S D$ \\
\hline \multirow[t]{3}{*}{ 05/01 } & $S$ & $2.73 \pm 1.08$ & $0.45 \pm 0.01$ & $30.33 \pm 0.57$ & $27.16 \pm 3.61$ & $6.90 \pm 0.62$ & $65.40 \pm 1.15$ & $7.50 \pm 1.24$ & $50.93 \pm 14.66$ & $0.55 \pm 0$ \\
\hline & M & & & $29.33 \pm 0.28$ & $24.50 \pm 1.50$ & $6.16 \pm 0.15$ & $69.40 \pm 1.20$ & $6.93 \pm 2.00$ & $52.55 \pm 55.41$ & \\
\hline & B & & & $29.00 \pm 0.00$ & $30.16 \pm 2.51$ & $6.06 \pm 0.11$ & $70.06 \pm 1.92$ & $3.43 \pm 2.13$ & $42.75 \pm 23.54$ & \\
\hline \multirow[t]{3}{*}{$12 / 01$} & $S$ & $2.30 \pm 1.05$ & $0.43 \pm 0.57$ & $32.00 \pm 0.00$ & $22.16 \pm 7.18$ & $7.46 \pm 0.90$ & $60.80 \pm 2.13$ & $8.43 \pm 1.36$ & $56.92 \pm 29.72$ & $0.40 \pm 0$ \\
\hline & M & & & $31.16 \pm 1.04$ & $24.00 \pm 4.09$ & $7.20 \pm 0.95$ & $60.50 \pm 2.41$ & $4.76 \pm 1.87$ & $33.83 \pm 11.07$ & \\
\hline & B & & & $30.00 \pm 1.00$ & $23.33 \pm 8.80$ & $6.30 \pm 0.26$ & $64.46 \pm 3.98$ & $3.16 \pm 0.85$ & $51.31 \pm 26.33$ & \\
\hline \multirow[t]{3}{*}{$19 / 01$} & $S$ & $2.46 \pm 1.15$ & $0.33 \pm 0.11$ & $30.33 \pm 1.52$ & $24.16 \pm 5.48$ & $6.76 \pm 0.05$ & $61.70 \pm 1.75$ & $5.80 \pm 1.83$ & $81.89 \pm 5.75$ & $0.35 \pm 0$ \\
\hline & M & & & $30.00 \pm 1.00$ & $24.33 \pm 0.28$ & $5.86 \pm 1.62$ & $105.50 \pm 79.27$ & $3.63 \pm 1.95$ & $76.27 \pm 40.31$ & \\
\hline & B & & & $29.66 \pm 1.15$ & $23.66 \pm 1.25$ & $6.73 \pm 0.05$ & $61.70 \pm 4.10$ & $3.90 \pm 2.08$ & $63.42 \pm 38.94$ & \\
\hline \multirow[t]{3}{*}{$26 / 01$} & $S$ & $2.80 \pm 1.15$ & $0.46 \pm 0.57$ & $29.66 \pm 1.15$ & $20.16 \pm 4.25$ & $7.53 \pm 0.70$ & $44.80 \pm$ & $6.20 \pm 0.65$ & $33.33 \pm 14.39$ & $0.90 \pm 0$ \\
\hline & M & & & $29.00 \pm 2.00$ & $19.16 \pm 2.46$ & $6.53 \pm 1.10$ & $45.60 \pm 3.75$ & $2.90 \pm 0.88$ & $28.71 \pm 1.71$ & \\
\hline & B & & & $28.66 \pm 0.57$ & $21.50 \pm 3.00$ & $6.13 \pm 0.90$ & $46.93 \pm 5.40$ & $2.40 \pm 1.81$ & $24.46 \pm 11.24$ & \\
\hline \multirow[t]{3}{*}{$02 / 02$} & $S$ & $2.80 \pm 1.15$ & $0.56 \pm 0.57$ & $32.66 \pm 3.78$ & $18.00 \pm 1.00$ & $5.46 \pm 0.56$ & $43.70 \pm 3.83$ & $5.96 \pm 1.05$ & $54.68 \pm 5.54$ & $0.39 \pm 0$ \\
\hline & M & & & $29.50 \pm 0.86$ & $16.33 \pm 4.16$ & $5.23 \pm 0.05$ & $44.50 \pm 3.13$ & $3.06 \pm 0.40$ & $52.05 \pm 13.75$ & \\
\hline & B & & & $29.00 \pm 0.00$ & $21.00 \pm 3.00$ & $5.00 \pm 0.00$ & $48.50 \pm$ & $1.76 \pm 0.98$ & $30.46 \pm 13.67$ & \\
\hline \multirow[t]{3}{*}{$09 / 02$} & $S$ & $2.63 \pm 1.10$ & $0.53 \pm 0.76$ & $29.16 \pm 0.28$ & $18.00 \pm 1.00$ & $4.70 \pm 0.10$ & $45.60 \pm 1.03$ & 1.04 & $30.33 \pm 14.00$ & $0.29 \pm 0$ \\
\hline & M & & & $28.66 \pm 0.57$ & $18.83 \pm 0.57$ & $4.93 \pm 0.23$ & $45.40 \pm 1.27$ & $3.23 \pm 1.26$ & $43.69 \pm 22.46$ & \\
\hline & B & & & $28.66 \pm 0.57$ & $18.50 \pm 0.50$ & $4.70 \pm 0.00$ & $46.90 \pm$ & $2.53 \pm 1.05$ & $34.70 \pm 16.26$ & \\
\hline \multirow[t]{3}{*}{$16 / 02$} & $S$ & $2.66 \pm 1.15$ & $0.63 \pm 0.10$ & $30.83 \pm 1.25$ & $25.66 \pm 3.54$ & $5.36 \pm 0.05$ & $44.70 \pm$ & $4.46 \pm 1.52$ & $42.69 \pm$ & $0.24 \pm 0$ \\
\hline & M & & & $29.16 \pm 0.28$ & $18.00 \pm 7.26$ & $5.36 \pm 0.25$ & $45.60 \pm 3.46$ & $2.50 \pm 0.60$ & $31.46 \pm 8.77$ & \\
\hline & B & & & $28.66 \pm 0.57$ & $21.00 \pm 6.00$ & $5.30 \pm 0.26$ & $52.60 \pm 13.73$ & $1.46 \pm 1.00$ & $29.21 \pm$ & \\
\hline \multirow[t]{3}{*}{$26 / 02$} & $S$ & $3.40 \pm 1.20$ & $0.43 \pm 0.11$ & $30.33 \pm 0.57$ & $16.66 \pm 1.15$ & $5.40 \pm 0.87$ & $36.70 \pm$ & $3.76 \pm 0.50$ & $6.74 \pm 2.57$ & $0.48 \pm 0$ \\
\hline & M & & & $28.33 \pm 1.15$ & $14.83 \pm 1.25$ & $5.40 \pm 0.75$ & $34.70 \pm$ & $2.50 \pm 0.60$ & $1.31 \pm$ & \\
\hline & B & & & $28.00 \pm 1.00$ & $15.33 \pm 3.32$ & $6.10 \pm 1.00$ & $37.60 \pm$ & $2.26 \pm 0.83$ & $5.24 \pm$ & \\
\hline
\end{tabular}

(X) Mean, (SD) standard deviation, (trans) transparency, (T) temperature, (Alk) alkalinity, (Cond) electrical conductivity, (DO) dissolved oxygen, (Chlor) chlorophyll-a, (L) water level, (-) loss of samples, (S) surface, (M) middle, (B) bottom.

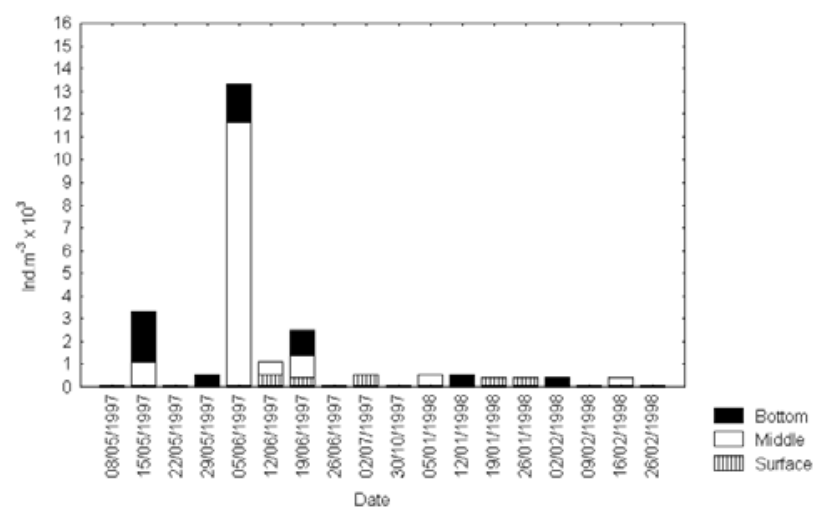

Figure 4. Density of Chaoboridae in Lago Amapá. controlling the distribution of these species, since the number of Chaoboridae in the middle of the water column was greater than in top or bottom. If some organisms had been affected by predation, they could have been the species Brachionus calicyflorus, Brachionus calicyflorus anuraeformis, Filinia terminalis, Keratella cochlearis hispida and Diaphanosoma spinulosum. This would have likely involved the first stages of Chaoboridae larvae, for they are more specific for rotifers.

In the high-water phase, there was a predominance of the taxa Brachionus calyciflorus and B. calyciflorus anuraeformis, Filinia opoliensis, Filinia terminalis and Keratella cochlearis hispida. Of these, only Filinia opoliensis and Filinia longiseta were also able to develop, although in smaller numbers, during the lowwater period.

Revista Brasileira de Zoologia 21 (2): 169-177, junho 2004 
With regard to the microcrustaceans, there was a greater abundance of Moina predominating in the low-water phase, especially in the middle of the water column, accompanying the presence of food.

This study showed that there was a concentration in the middle of the water column of some species of rotifers including Brachionus falcatus, Brachionus calicyflorus, Brachionus calicyflorus anuraeformis, Filinia opoliensis, Keratella cochlearis hispida and of the microcrustacean Moina minuta. The presence of these species in this niche is possibly explained by the levels of chlorophyll- $a$ and dissolved oxygen, which were shown to be relatively high. According to Williamson et al. (1996), food specific for planktonic organisms is approximately three times more elevated in the middle of the water column than in the top layer.

When stratified, lakes produce compartmentalization and a vertical gradient in the distribution of the planktonic communities, in contrast to what was observed in Lago Amapá. The absence of stratification and the presence of food, acting together, explains possibly the abundance of these species in the middle of the water column.

During the entire period studied, the levels of dissolved oxygen showed a pronounced difference between the top and bottom layers with the greater values being limited to the upper layers, explaining the absence of zooplanktonic organisms at the bottom of the lake.

Fisher et al. (1983) observed during a 24-h cycle at Lago Calado, that the zooplankton was stratified in relation to dissolved oxygen, always being in or moving toward the most oxygenated layer during the day. LANSAC-TÔHA et al. (1992) also noted that some calanoid cladocers and copepodites were distributed preferentially in layers where the concentration of dissolved oxygen was more elevated.

The larvae of Chaoboridae also regulated the presence of plankton, although to a much lesser extent compared to the physico-chemical parameters. The numbers found demonstrated the presence of a high concentration of these larvae in the bottom followed by the middle layer of the water column. According to Neill \& Peacock (1980) apud Havens (1990), rotifers are the principal source of food for the first stages of Chaoboridae. Arcifa (1997) reported that Chaoborus spp. have the potential for predation during the entire year, whereby the pressure on the plankton is diminished by the seasonal fluctuations of the population and its vertical migration. In the latter study, population growth during the warm-rainy season reached a level of 4 ind. $\mathrm{L}^{-1}$.

Nonetheless, in Lago Amapá a maximum of 12,000 ind. ${ }^{-3}$ occurred, possibly influencing the presence of zooplankton, mainly the cladocers, which are the preferred food for these larvae.

During low water, there was blooming period for the Cyanophyceae algae, observed by chance in great abundance in samples, in addition to being visible to the naked eye in
Lago Amapá. The effect of blue-green algae (toxic) on the structure of zooplankton communities, influenced the distribution of some species in this study, which migrated to the bottom of the lake during this phase, probably in search of adequate food.

The low diversity in Lago Amapá must have been affected by the increase in the water level, despite a fluctuation varying at least $2 \mathrm{~m}$ during the whole hydrologic cycle. According to the explanation provided by the intermediate disturbance hypothesis, if the disturbances are moderate or rare, the groups then tend toward an equilibrium and few species dominate, since this equilibrium eliminates other species (CONNELL 1978), through the competition for niches, food and predation. Therefore, a moderate disturbance occurred in the environment studied here.

Various factors, such as the competition for food, predation, presence of light, and temperature, acted together to determine the presence of zooplankton populations in a particular niche in the water column, whereby physical and chemical parameters were determinants.

\section{ACKNOWLEDGMENTS}

We give special thanks to Dr. Janet Reid for the confirmation and identification of the copepods. We are grateful to Dr. Cláudia Costa Bonecker (Nupélia, Universidade Estadual de Maringá, PR), Suzana Sendacz (Instituto de Pesca, SP), and Pedro González Dominguez (Universidade Federal do Acre, AC) for their valuable critique of this study and part of the Masters dissertation in Ecology and Management of Natural Resources. Universidade Federal do Acre. We also thank Willians Monteiro Ayache (technician, Department of Natural Sciences,) for his help with samplings at Lago Amapá.

\section{REFERENCES}

ArCifa, M.S. 1997. Fluctuations and vertical migration of Chaoborus in a tropical Brazilian reservoir: Lake Monte Alegre. Acta Limnologica Brasiliensia, São Paulo, 9: 93103.

Bini, L.M.; C.C. Bonecker; F.A. LANSAC-Tôha. 2001. Vertical distribution of rotifers on the Upper Paraná River floodplain: the role of thermal stratification and chlorophyll $a$. Studies on Neotropical Fauna and Environmental, Lisse, 36 (3): 241-246.

Connell, J. 1978. Diversity in tropical rain forests and coral reefs. Science, Washington, 199: 1302-1309.

Esteves, F.A.; S.M. Thomaz \& F. Roland. 1994. Comparison of the metabolism of two floodplain lakes of the Trombetas River (Pará, Brazil) based on a study of diel variation. Amazoniana, Plön, 13: (1/2): 33-46.

Fisher, T.R.; J.M. Melack; B. Robertson; E.R. Hardy \& L.F. Alves. 1983. Vertical distribution of zooplankton and physicochemical condition during a 24-hour period in an Amazon floodplain lake - Lago Calado, Brazil. Acta Amazonica, Manaus, 13 (3-4): 475-487.

Revista Brasileira de Zoologia 21 (2): 169-177, junho 2004 
Golterman, H.L.; R.S. Clymo \& M.A.M. OhMSTAD. 1969. Methods for Chemical Analysis of Fresh waters - IBP. Oxford, Blackwell Scientific Publications, Handbook 8, $1^{\text {st }}$ ed., XVI+ 215p.

Golterman, H.L.; R.S. Clymo \& M.A.M. Ohmstad. 1978. Methods for physical and chemical analysis of Fresh waters. Oxford, Blackwell Scientific Publications, Handbook 8, $2^{\text {nd }}$ ed., 213p.

Harper, J.L. 1978. Population Ecology of Plants. London, Academic Press, 892p.

Havens, K.E. 1990. Chaoborus predation and zooplankton community structure in a rotifer-dominated lake. Hydrobiologia, Dordrecht, 198: 215-226.

KreBs, C.J. 1989. Ecological Methodology. New York, Harper Collins, 654p.

Infante, A. 1980. Los rotiferos del Lago de Valencia. Acta Cientifica Venezolana, Caracas, 31: 30-47.

Lansac-TôHa, F.; A.F. Lima; S.M. Thomaz \& M.C. Roberto. 1992. Zooplâncton de uma planície de inundação do rio Paraná. I. Análise qualitativa e estrutura da comunidade. Revista Unimar, Maringá, 14 (Suppl.): 35-55.

Lewis, W.M. \& F.H. Weibezahn. 1976. Chemistry, energy flow, and community structure in some Venezuelan fresh waters. Archiv für Hydrobiologie, Plön, (Suppl. 50): 145-207.

Neill, W.E. \& A. Peacock. 1980. Interaction of toxicants and communities: the role of nutrients. Environmental toxicology and chemistry, Elmsford, 13: 361-368.

Mackereth, F.J.H.; J. Heron \& F.J. Talling. 1978. Water analysis some revised methods for limnologist. Kendall Titus, Wilson \& Sons, 117p.

Paes da Silva, L. \& S.M. Thomaz. 1997. Diel variation of some limnological parameters and metabolism of a lagoon of the high Paraná River floodplain, MS. Anais do VIII Seminário Regional de Ecologia, São Carlos, 8: 169-189.

ReYNoldS, C.S.; J. PADISAK \& U. SOMMER. 1993. Intermediate disturbance in the ecology of phytoplankton and the maintenance of species diversity: A synthesis. Hydrobiologia, Dordrecht, 249: 183-188.

Salati, E.; J. Marques; L.C.B. Molion. 1978. Origem e distribuição das chuvas na Amazônia. Interciência, Caracas, 3: 200-206.

Sioli, H. 1968. Principal Biotopes of Primary Production in the Water of Amazonia, p. 591-600. In: R. Misra \& B. Gopal (Eds). Proceeding Symp. Recent Adv. Tropical Ecology. Varanasi, The International Society for Tropical Ecology.

SIoli, H. 1984. The Amazon and its main affluents: Hydrography, morphology of the river courses, and river types, $\mathrm{p}$. 127-165. In: H. Sioli (Ed.). The Amazon: Limnology and landscape ecology of a mighty tropical river and its basin, Monographiae biologicae. Dordrecht, W. Junk Publishers, 763p.

Williamson, C.E.; R.W. SAunders, R.E. Moeller \& P.L. Stutzman. 1996. Utilization of subsurface food resources for zooplankton reproduction: Implications for diel vertical migration theory. Limnology Oceanography, Edmonton, Alberta, 41 (2): 224-233.

Received in 14.XI.2003; accepted in 13.V.2004. 